\title{
Low Birth Weight \& Associated Factors Among Newborns in Gondar Town, North West Ethiopia: Institutional Based Cross- Sectional Study
}

\author{
Kahsay Zenebe ${ }^{1 *}$, Tadese Awoke ${ }^{2}$, Nigusie Birhan ${ }^{3}$ \\ ${ }^{1}$ Department of Midwifery, College of Medicine and Health Sciences, University of Gondar, Ethiopia \\ ${ }^{2}$ Department of Biostatics and Epidemiology, Institute of Public Health, University of Gondar, Ethiopia \\ ${ }^{3}$ Department of Nursing, College of Medicine and Health Sciences, University of Gondar, Ethiopia
}

Address for Correspondance: Kahsay Zenebe, kahsay.zenebe@gmail.com

\begin{abstract}
BACKGOUND: Reducing infant mortality is a global priority which is particularly relevant in developing countries including Ethiopia. One of the key strategies to reduce infant mortality rate and improving child health is improving birth weight; however, low birth weight is significantly higher in Ethiopia. The main aim of this study was to determine prevalence and identify associated factors of low birth weight among newborns in Gondar town, North West Ethiopia. METHODS: An institution based cross-sectional study was employed. Systematic sampling was used to select 540 study participants. A pre tested and structured questionnaire was used to collect data. The data was entered, cleaned and edited using EPI INFO version 2002 and exported to SPSS version 16.0 software packages for analysis. Both bivariate and multiple logistic regression were fitted and odds ratio and $95 \%$ CI were computed to identify associated factors and determine the strength of association. A p-value of $<0.05$ was considered as statistical significant. RESULT: The response rate was $100 \%$. The mean gestational age of the newborns was $39.49 \pm 1.53$ weeks. The mean age of the respondents was $25.8 \pm 5.5$ years. The overall prevalence of low birth weight was $17.4 \%$. The covariates pregnancy-induced hypertension (AOR 9.2(95\% CI 3.36, 25.3)), malaria attack during pregnancy (AOR 4.9(95\%CI 1.95, 12.3)), female sex newborn (AOR 2.1, $(95 \% \mathrm{CI} 1.18,3.76)$ ) and gestational age less than 37 weeks (AOR 18, 95\%CI 5.8, 31.2)) were found to be significantly associated with birth weight of new born. CONCLUSION: There was a high prevalence of low birth weight in the study area. Effective treatment and preventive of malaria and pregnancy induced hypertension; prevention of preterm birth could reduce low birth weight. (C) 2014 iGlobal Research and Publishing Foundation. All rights reserved.
\end{abstract}

KEYWORDS: New Borns; Low Birth Weight; Cross Sectional Study

\section{INTRODUCTION}

According to the World Health Organization (WHO) definition, infants with birth weight less than $2500 \mathrm{~g}$ are low birth weight (LBW) (1). Out of 121 millions births in a year 23 million have LBW and high proportion of which are found in developing countries (2). 


\section{Indo Global Journal of Pharmaceutical Sciences, 2014; 4(2): 74-80}

Birth weight is an important indicator of health status of an infant and is a principal factor that determines the infant's, physical, survival and mental growth. It also indicates past and present health status of the mother (3, 4). LBW is considered as the single most important predictor of infant mortality, especially of deaths within the first months of life (5). It is also a significant determinant of infant and childhood morbidity, particularly of neurodevelopment impairment such as mental retardation and learning disability (6).

Half of all perinatal and one third of all infant deaths are directly or indirectly related to LBW (7). Mortality of LBW babies is 40 times more than the normal -weight babies (8). Infants born with very low weight are more than 100 times more likely to die in the first year of life than are infants of normal birth weight (9).

The third target of World Health Organization (WHO) document "Health for All in 21 Century" has stated that "by the year 2020 all newborn babies. The primary objective for the implementation of this target is to reduce the number of infants born below $2500 \mathrm{~g} \mathrm{(10)}$.

According to UNICEF statistics, the global rate of LBW is $17 \%$, out of which $6 \%$ is observed in industrialized countries and $21 \%$ in developing (11); LBW is caused by preterm birth and intrauterine growth retardation (IUGR) or both. The predominant cause of LBW in the developed is preterm birth, whereas in developing countries, it is frequently caused by IUGR (10).

The WHO country cooperation strategy 2008 2011 showed that the prevalence of low birth weight in Ethiopia, estimated that $14 \%$, it is one of the highest in the world (12).

The forth Millennium Development Goal (MDG) aims to improve child and infant health with a target of reducing under-five mortality at the rate of 5.2 per 1,000 live births each year starting in the 1990s -However, between 1990 and 2000, the rate of decrease of under-five mortality has only been about 1.9 per 1,000 live births per year. Moving forward, Ethiopia would have to reduce child mortality by 7.4 per 1,000 live births per year during the period 20032015 to achieve the MDG target And the report on progression implanting the world fit for children plan of action in Ethiopia result indicate that short birth interval, high birth order, LBW and young age of mother are strongly linked to high child mortality levels (13). As the prevalence of LBW is one of the most important health indices and it is important to know the prevalence and risk factors for LBW in different areas. The results of this study will help to inform the health authorities about the local risk factors for $\mathrm{LBW}$ in order to introduce programmes to reduce its prevalence

\section{METHODS}

Institutional based cross sectional study was conducted among Mothers along with newborn in health institutions Gondar town. The study was conducted in Gondar town which is located in north Gondar, Amhara Regional state Northwest Ethiopia. Gondar is located $745 \mathrm{~km}$ away from Addis Ababa, the capital of Ethiopia. Gondar town has a total population of 248784(117673 male and 131111 female). Female in reproductive age groups (15-49 years) are 58863 (28). There are 6 governmental and 3 private health institutions which provide services related to delivery. The study was conduct from March to May, 2012.

The study populations were mothers with newborns who gave birth during the study period at Gondar town health institution. All singleton alive newborns with mothers delivered in health institutions during the study period were included in the study.

Systematic sampling was employed to select study participants from each health institution. By considering average numbers of clients who deliver daily during data collection period was estimated based on the previous daily client flow of the units was obtained by referring client registration book/ record for a month prior to data collection.

Using single population proportion formula the finally sample size was found to be 540 .

Data was collected by face to face interviews using a structured and pre-tested questionnaire. Training was given for both data collectors and supervisors. Data entry was done by using EPI Info 2002 and exported to SPSS version 16.0 software package for analysis. Multivariate logistic regression was fitted to determine the effect of various factors on the outcome variable. The degree of association between independent and dependent variables were assessed using odds ratio with 95\% confidence interval.

Ethical clearance was obtained from Institutional Review Board (IRB) of University of Gondar. Formal letter of cooperation was written for Gondar Woreda health department and each health institution. Verbal and written consent was obtained from each study participant.

\section{RESULTS}

\section{Socio-demographic characteristics}

Out of the total respondents, 357(66.1\%) were urban residents. The mean age of the respondents was $25.8 \pm 5.5$ years. Majority of respondents $(81.3 \%)$ were between ages $20-35$ years old. With regard to sex of newborn, 
Indo Global Journal of Pharmaceutical Sciences, 2014; 4(2): 74-80

$311(57.6 \%)$ were male. Regarding marital status of the mothers, most $500(92.6 \%)$ were married. Most of the mothers, 337 (62.4\%) were house wives (Table 1).

\section{Maternal and Obstetric characteristics}

Four hundred eighty five (89.8\%) mothers have ANC follow up during the course of pregnancy. Three hundred twenty four $(66.8 \%)$ have four and above antenatal care visit during their pregnancy. Out of 540 mothers 275 $(50.9 \%)$ was primigravid. Regardless of anemia of the mothers $112(20.7 \%)$ were screened. Out of them 17 (15.17\%) were anemic. Out of 540 women 499(92.4\%) were tested for HIV infection and 28(5.6\%) were positive for the infection. Out of the 540 mother 27(5\%) were have UIT (Table 2).

Table: 1. Socio-Demographic characteristics of respondents, Gondar, Northwest, Ethiopia, 2012

\begin{tabular}{|c|c|c|}
\hline Variable & Frequency & Percent \\
\hline $\begin{array}{l}\text { Residence } \\
\text { Urban } \\
\text { Rural }\end{array}$ & $\begin{array}{l}357 \\
183\end{array}$ & $\begin{array}{l}66.1 \\
33.9\end{array}$ \\
\hline $\begin{array}{l}\text { Age } \\
\leq 19 \\
20-34 \\
\geq 35\end{array}$ & $\begin{array}{c}64 \\
441 \\
35\end{array}$ & $\begin{array}{c}11.9 \\
81.6 \\
6.5\end{array}$ \\
\hline $\begin{array}{l}\text { Religion } \\
\text { Orthodox } \\
\text { Muslim } \\
\text { Others }\end{array}$ & $\begin{array}{c}474 \\
61 \\
5\end{array}$ & $\begin{array}{c}87.7 \\
11.3 \\
1\end{array}$ \\
\hline $\begin{array}{l}\text { Educational Status } \\
\text { Unable to read \&write } \\
\text { Read and write } \\
\text { Primary education } \\
\text { Secondary education and college }\end{array}$ & $\begin{array}{c}145 \\
13 \\
103 \\
279\end{array}$ & $\begin{array}{c}26.8 \\
2.4 \\
19.1 \\
51.7\end{array}$ \\
\hline $\begin{array}{l}\text { Marital Status } \\
\text { Married } \\
\text { Divorced/separated } \\
\text { Widowed }\end{array}$ & $\begin{array}{c}500 \\
39 \\
1\end{array}$ & $\begin{array}{l}92.6 \\
7.2 \\
0.2\end{array}$ \\
\hline $\begin{array}{l}\text { Nation and Nationality } \\
\text { Amhara } \\
\text { Tigre } \\
\text { Oromo }\end{array}$ & $\begin{array}{c}525 \\
13 \\
2\end{array}$ & $\begin{array}{l}97.2 \\
2.4 \\
0.4\end{array}$ \\
\hline $\begin{array}{l}\text { Occupational status } \\
\text { Housewife } \\
\text { Gov't employer } \\
\text { private employee } \\
\text { daily laborer } \\
\text { Farmer }\end{array}$ & $\begin{array}{l}337 \\
79 \\
44 \\
70 \\
10\end{array}$ & $\begin{array}{c}62.4 \\
14.7 \\
8.1 \\
13 \\
1.9\end{array}$ \\
\hline
\end{tabular}


Indo Global Journal of Pharmaceutical Sciences, 2014; 4(2): 74-80

Table: 2. Obstetrics and maternal condition of the respondents in Gondar health institution, North West Ethiopia, March- May, 2012.

\begin{tabular}{|c|c|c|}
\hline Variable & Frequency & Percent \\
\hline $\begin{array}{l}\text { Parity } \\
\text { Primigravid } \\
\text { MultiPara }\end{array}$ & $\begin{array}{l}275 \\
265\end{array}$ & $\begin{array}{l}50.9 \\
49.1\end{array}$ \\
\hline $\begin{array}{c}\text { ANC } \\
\text { Yes } \\
\text { No }\end{array}$ & $\begin{array}{c}485 \\
55\end{array}$ & $\begin{array}{c}89.8 \\
10.18\end{array}$ \\
\hline $\begin{array}{l}\text { Number of } \\
\text { ANC } \\
\quad<4 \\
\geq 4\end{array}$ & $\begin{array}{l}161 \\
324\end{array}$ & $\begin{array}{c}33.19 \\
66.8\end{array}$ \\
\hline $\begin{array}{l}\text { Hgb done } \\
\text { Yes } \\
\text { No }\end{array}$ & $\begin{array}{l}112 \\
428\end{array}$ & $\begin{array}{l}20.7 \\
79.3\end{array}$ \\
\hline $\begin{array}{l}\text { Hgb } \\
\quad<11 \\
\geq 11\end{array}$ & $\begin{array}{l}17 \\
95\end{array}$ & $\begin{array}{l}15.17 \\
84.82\end{array}$ \\
\hline $\begin{array}{l}\text { HIV tested } \\
\text { Yes } \\
\text { No }\end{array}$ & $\begin{array}{c}499 \\
41\end{array}$ & $\begin{array}{c}92.4 \\
7.6\end{array}$ \\
\hline $\begin{array}{l}\text { HIV status } \\
\text { Positive } \\
\text { Negative }\end{array}$ & $\begin{array}{c}28 \\
471\end{array}$ & $\begin{array}{c}5.6 \\
94.4\end{array}$ \\
\hline $\begin{array}{l}\text { UTI } \\
\text { Yes } \\
\text { No }\end{array}$ & 513 & $\begin{array}{c}5 \\
95\end{array}$ \\
\hline
\end{tabular}

\section{Characteristics of infants}

Mean birth weight of the infants was $2.9 \pm 467.7 \mathrm{~kg}$ (range 1.5 to 4.3 ). The mean gestational age of the newborns was $39.49 \pm 1.53$ weeks with minimum 31 and maximum 44 weeks. The prevalence of low birth weight was found to be $17.4 \%$ ( $22.7 \%$ female and $13.5 \%$ male). Out of the 540 newborn $516(95.5 \%)$ was delivered at greater than or equal to 37 weeks gestation. Of the total under weight babies $76(14.7 \%)$ were term small-for gestational age infants and $18(75 \%)$ preterm were low birth weight (figure 1)

\section{Factors associated with low birth weight}

The covariates pregnancy induced hypertension, malaria attack during pregnancy, being female sex and gestational age less than 37 week was found to be significantly associated with low birth weight in multiple logistic regression analysis.

Those women with $\mathrm{PIH}$ were 9 times $(\mathrm{AOR}=9.23$, $95 \% \mathrm{CI}=3.36,25.36)$ more likely to deliver low birth weight baby than those women without PIH. Malaria during pregnancy was also a risk factor for low birth weight. 
Indo Global Journal of Pharmaceutical Sciences, 2014; 4(2): 74-80

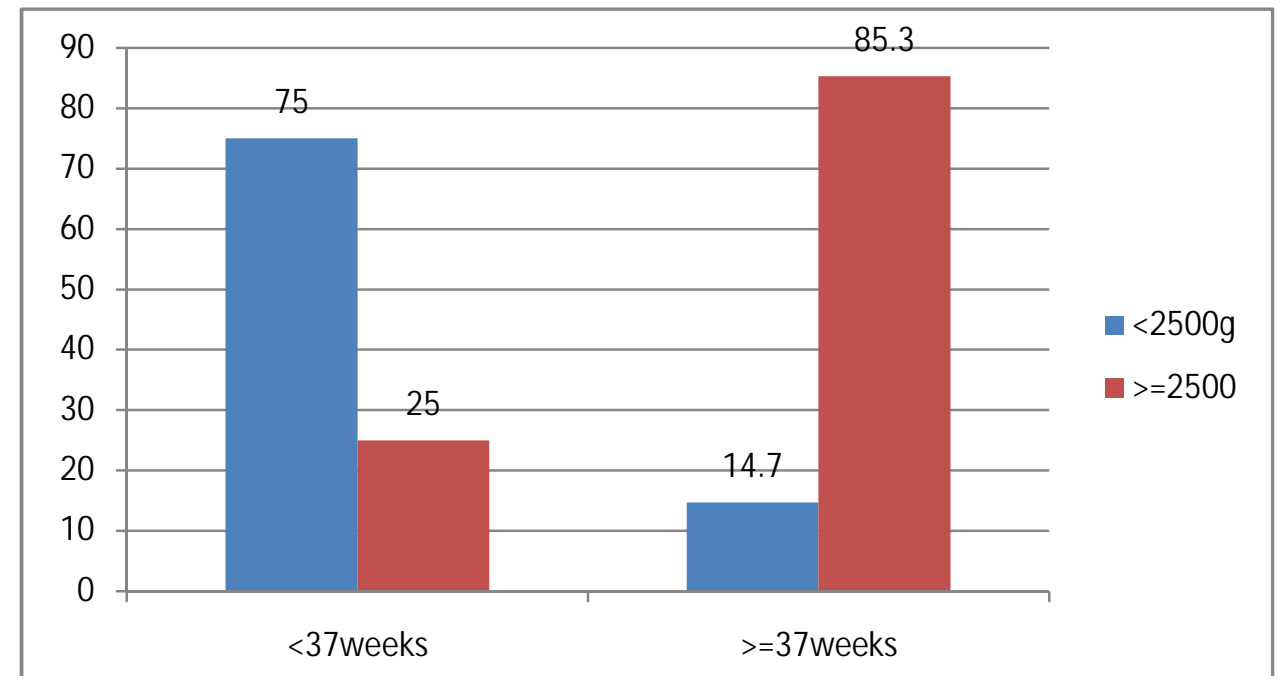

Fig: 1. Show birth weight based on their gestational age in Gondar town health institutions from March -May 2012.

Table: 3. Bivariate and multiple logistic regression of selected variables in relation to birth weight among (n=540) newborn delivered in Gondar town health institution 2012.

\begin{tabular}{|c|c|c|c|c|}
\hline Variable & Lo & weight & $\operatorname{COR}(95 \% \mathrm{CI})$ & $\operatorname{AOR}(95 \% \mathrm{CI})$ \\
\hline & Yes & No & & \\
\hline $\begin{array}{l}\text { Residence } \\
\text { Urban } \\
\text { Rural }\end{array}$ & $\begin{array}{l}51 \\
43 \\
\end{array}$ & $\begin{array}{l}306 \\
140 \\
\end{array}$ & $\begin{array}{l}1.00 \\
1.843(1.172,2.897) \\
\end{array}$ & \\
\hline $\begin{array}{l}\text { Educational status } \\
\text { unable to read and write } \\
\text { Read and write } \\
\text { primary education } \\
\text { secondary education and } \\
\text { college }\end{array}$ & $\begin{array}{l}29 \\
2 \\
27 \\
36\end{array}$ & $\begin{array}{l}116 \\
11 \\
76 \\
243\end{array}$ & $\begin{array}{l}1.687(0.987,2.886) \\
1.227(0.261,5.768) \\
1.398(0.368,4.205) \\
1.00\end{array}$ & \\
\hline $\begin{array}{l}\text { PIH } \\
\text { Yes } \\
\text { No }\end{array}$ & $\begin{array}{l}18 \\
76\end{array}$ & $\begin{array}{l}10 \\
436\end{array}$ & $\begin{array}{l}10.326(4.591,23.224) \\
1.00\end{array}$ & $\begin{array}{l}9.23(3.36,25.36) * \\
1.00\end{array}$ \\
\hline $\begin{array}{l}\text { Cardiac } \\
\text { Yes } \\
\text { No }\end{array}$ & $\begin{array}{l}4 \\
90 \\
\end{array}$ & $\begin{array}{l}5 \\
441 \\
\end{array}$ & $\begin{array}{l}3.920(1.032,14.884) \\
1.00\end{array}$ & \\
\hline $\begin{array}{l}\text { Malaria } \\
\text { Yes } \\
\text { No }\end{array}$ & $\begin{array}{l}19 \\
75\end{array}$ & $\begin{array}{l}20 \\
426\end{array}$ & $\begin{array}{l}5.396(2.750,10.589) \\
1.00\end{array}$ & $\begin{array}{l}4.9(1.95,12.32) * \\
1.00\end{array}$ \\
\hline $\begin{array}{l}\text { ANC } \\
\text { Yes } \\
\text { No } \\
\end{array}$ & $\begin{array}{l}81 \\
13 \\
\end{array}$ & $\begin{array}{l}405 \\
41 \\
\end{array}$ & $\begin{array}{l}1.00 \\
1.585(0.813,3.093) \\
\end{array}$ & \\
\hline $\begin{array}{l}\text { Sex } \\
\text { Male } \\
\text { Female }\end{array}$ & $\begin{array}{l}42 \\
52\end{array}$ & $\begin{array}{l}269 \\
177\end{array}$ & $\begin{array}{l}1.00 \\
1.88(1.2,2.9)\end{array}$ & $\begin{array}{l}1.00 \\
2.1(1.18,3.76) *\end{array}$ \\
\hline $\begin{array}{l}\text { Gestational age } \\
<37 \\
\geq 37\end{array}$ & $\begin{array}{l}18 \\
76\end{array}$ & $\begin{array}{l}6 \\
440\end{array}$ & $\begin{array}{l}17.36(6.68,45.1) \\
1.00\end{array}$ & $\begin{array}{l}18(5.84,31.2) * \\
1.00\end{array}$ \\
\hline
\end{tabular}




\section{Indo Global Journal of Pharmaceutical Sciences, 2014; 4(2): 74-80}

Those women attacked by malaria during pregnancy were 5 times $(\mathrm{AOR}=4.9,95 \% \mathrm{CI}=1.95,12.32)$ more likely to deliver low birth weight baby than their counterparts.

Sex of the infant was significantly associated with birth weight; being female has two fold risks for low birth weight. $\quad(\mathrm{AOR}=2.1,95 \% \mathrm{CI} 1.18,3.76)$. Those newborns with gestational age less than 37 weeks were 18 times $(\mathrm{AOR}=18,95 \% \mathrm{CI} 5.84,31.2)$ more likely to be delivered low birth weight than those new born greater than or equal to 37 weeks of gestation(Table 3 ).

\section{DISCUSSION}

The study results revealed that the prevalence of low birth weight was $17.4 \%$. This is lower than the research done in Jimma (22.5\%) (21). But it is higher when comparing with research done in southwest Ethiopia (22), this might be due to study area difference.

This finding was high as compared with the research done in Iran and Malawi $(14,17)$. The difference might be due to the fact that, mothers in these countries have better disease screening and prevention and also there might be gate better nutrient before and after conception. This study finding is higher than study done in the turkey Istambul Maternity and Children Teaching Hospital which was $(9.14 \%)$ and in Nepal Dhulikhel hospital $(11.07 \%)(20,25)$. The difference might be due to the fact that, mothers in these countries have better health service and also there might be better weight gain.

Pregnancy induced hypertension one of the risk factors for LBW and this finding was in line with other studies done in Iran (14). Similar finding was also reported from the study done in India which revealed that mothers with PIH were more likely to delivery low birth weight as compared with those women without PIH (19). This is again supported by a research done in Malaysia which mother with $\mathrm{PIH}$ was three times more risk to delivery LBW infant than mother without PIH (26). This might be due to hypertension results in decreased blood flow through the spiral arterioles and decreased delivery of oxygen and nutrients to the placenta and fetus and Hypertension also might be associated with placental infarction (29).

This study found that malaria attacked during pregnancy was found to be risk for LBW which is similar to previous studies done in Zahedan, Islamic republic of Iran which was mothers with infection during pregnancy were more likely delivered LBW baby than without infection (16). This might be due to the parasite have affinity for deciduas vessel and involve the placenta and decrease nutrient and oxygen transmitted to the fetus in addition to this it might be a risk factor for pre term birth(30).

Sex of the newborn is another factor found to be significantly affecting the weight of newborn. Being female sex was more likely to be LBW as compared with male. This finding is similar with the study done in southwest Ethiopia (22). Study done in Iran has also shown that female sex was more likely to be LBW than males (15). This might be due to androgen hormone promote the enlargement of skeletal muscle cells in males.

The results of the present study also revealed that the birth weight is significantly influenced by gestational age. Newborn with gestational age of less than 37 weeks was more likely to be LBW as compare to gestational age greater than or equal to 37 weeks. This finding is in agreement with study conducted in Jimma (21). This also support by research reported from study done in Italy, Iran and Tanzania, which shows significant association of gestational age with the weight of the newborn $(18,14,27)$. This again support by a research done in Malaysian gestational age was of the risk factor for LBW (26). This might be due to did not reach the optimal time which greater than or equal to 37 weeks of gestation.

\section{CONCLUSON}

The prevalence of low birth weight in the study area was high. The covariate pregnancy induced hypertension, malaria attacked during pregnancy, female sex and gestational age less than 37 weeks were the major risk factors for low birth weight. Effective treatment and prevention of malaria and pregnancy induced hypertension; prevention of preterm birth could reduce low birth weight

\section{COMPETING INTERESTS}

The authors declare that they have no competing interests.

\section{AUTHOR'SCONTRIBUTIONS}

$\mathrm{KZ}$ wrote the proposal, participated in data collection, analyzed the data and drafted the paper. TA and NB approved the proposal with some revisions, participated in data analysis and revised subsequent drafts of the paper. All authors read and approved the final manuscript. 


\section{Indo Global Journal of Pharmaceutical Sciences, 2014; 4(2): 74-80}

\section{ACKNOWLEDGEMENT}

We are very grateful to the University of Gondar for the approval of the ethical clearance and for their technical and financial support of this study. Then, we would like to thank all mothers who participated in this study for their commitment in responding to our interviews.

\section{REFERENCES}

1. Centers for Disease Control and Prevention. International notes update: incidence of low birth weight. In Morbidity and Mortality Weekly Report (MMWR). CDC, Atlanta1984, 459460.

2. Roudbari M, Yaghmaei M, Soheili M. Prevalence and risk factors of low-birth-weight infants in Zahedan, Islamic Republic of Iran. East Mediter Health J. 2007; 13: 838-845.

3. Ramkutty P, Tikreti RAS, Resam KW. A study on birth weight of Iraqi children. J Trop Pediatr. 1983; 29:5-10.

4. Louangpradith Viengsakhone1, 2, Yoshitoku Yoshida1, MD, harun-or-rashid1 and Junichi. Determinant of low birth weight in Vientiane Laos, Sakamoto1 nagoya J.Med. Scl, 2010,72.5158

5. Ryan CA, Ryan F, Keane E, Hegarty H. Trend analysis and socio-economic differentials in infant mortality in the Southern Health Board, Ireland. Ir Med J. 2000; 93(7):204-6.

6. Chiarotti F, Castignani AM, Puopolo M, et al. Effects of socio environmental factors on neurocognitive performance in premature or low-birth weight preschoolers. Ann Ist Super Sanita. 2001; 37:553-9.

7. Aurora S, Vishnu Bhat B. Habibullah S, Srinivasan S, Puri RK, Rajaram P. Maternal nutrition and birth weight. Indian J Mat Child Hlth. 1994; 5: 73-75.

8. In: Martin RJ, Fanaroff AA, Walsh MC, 8th ed. Fanaroff and Martin Neonatal-Perinatal Medicine. Disease of the fetus and infant. Philadelphia: Elsevier, 2006:19.

9. U.S. Department of Health and Human Services, Health Resources and Services Administration, Maternal and Child Health Bureau. Child Health USA 2011. Rockville, Maryland: U.S. Department of Health and Human Services, 2011.

10. WHO Regional Office for Europe the Introduction to Health for all policy for the WHO European Region. Copenhagen: Health $21 ; 1998$

11. Bellamy UNICEF. The State of the World's Children, 2000. Progress since the World Summit for Children: A statistical review. New York: United Nations Children's Fund, 2001. Available at: http://www.unicef.org/sowc00. Accessed February 2007.

12. WHO. Nutrition and food safety, WHO country cooperation strategy 2008-2011, Ethiopia, page12

13. Government of Ethiopia. Status of child health. Report on progression implementing the world fit for children plan of action in Ethiopia.2007,page 18

14. Golestan M, Akhavan Karbasi S, Fallah R prevalence and risk factors for LBW in Yazd, a central city of Iran Singapore. Med J 2011; 52(10): 730-73.
15. Fatemeh Emamghorashi; M.D.;Seyyedn Taghi Heydari; M.D. neonatal birth weight and related factors in south of Iran, Jahrom; journal of family and reproductive health, 2008, 2(4), 191-193

16. M. Roudbari,M. Yaghmaei and M Soheili' Prevalence and risk factors of low-birth-weight infants in Zahedan, Islamic Republic of Iran, World health organization eastern meditrraian health journal 2007, 13(4),838-845.

17. AS Muula, ${ }^{1}$ S Siziya, ${ }^{2}$ and E Rudatsikira ${ }^{3,4}$ Parity and maternal education are associated with low birth weight in Malawi, Afr Health Sci. 2011; 11(1): 65-71.

18. Lasker JN, Coyle B, Li K, Ortynsky M. Assessment of risk factors for low birth weight deliveries. Health Care Women Int. 2005; 26:262-80.

19. Mumbare SS, Maindarkar G, Darade R, Yenge S, Tolani MK, Patole K, maternal risk factors associated with full term low birth weight (LBW) neonates, Indian Pediatr. 2011. pii: S09747559INPE1000229-1.

20. Emel Altuncu, Sultan Kavuncuoğlu, Pınar Özdemir Gökmirza, Zeynel Albayrak, Ayfer Arduç, The incidence of low birth weight in 5000 live born infants and the etiology of fetal risk factors, Marmara Medical Journal 2006;19(2);46-51

21. Tema T. Prevalence and determinants of low birth weight in Jimma Zone, Southwest Ethiopia, East Afr Med J. 2006 ;83(7):366-71.

22. Nekatibeb G, G/Mariam A, Analysis of birth weight in Metu Karl hospital: South West Ethiopia, Ethiop Med J. 2007; 45(2):195-202.

23. Department of Community Medicine Mercer University School of Medicine Quantitative Data Analysis of Multiple Factors Associated with Low Birth Weight in Bibb County,Georgia, Journal of the Georgia Public Health Association,2008,1(1),24-32

24. Jolanta Dičkutè, Žilvinas Padaiga, Vilius Grabauskas, Rūta Jolanta Nadišauskienè1, Vytautas Basys2, Aldona Gaižauskienė3, maternal socio-economic factors on the risk of low birth weight in Lithuania. Medicina (Kaunas) 2004; 40(5), 475-482

25. S. D. Singh 1, S. Shrestha 1, S. B.Marahatta 2, Incidence and risk factors of low birth weight babies born in Dhulikhel Journal of Institute of Medicine, 2010;32(3), 39-42.

26. N Y Boo, S M Lim, K T Koh, K F Lau, J Ravindran, Risk factors associated with low birth weight infants in the Malaysian population, Medical journal of Malaysia (2008) Volume: 63, Issue: 4, Pages: 306-310

27. J.E. SIZA, Risk factors associated with low birth weight of neonates among pregnant women attending a referral hospital in northern Tanzania, Tanzania Journal of Health Research (2008), Vol. 10, No. 1, 1-8.

28. Gondar woreda annual health report, 2004 E.C.

29. Alan H. DeCherney, MD, Lauren Nathan, MD, T. Murphy Goodwin, MD, Neri Laufer, MD,current diagnosis and treatment obstetrics and gynecology, new work, new work Chicago san Juan seoul Singapore Sydney Toronto,2007, 10.

30. F.gary cunnigghn, Kenneth, steven 1, bloom, johne, larry c, Williams obstetrics, united state of America, medical publishing, 2005,22 edition. 